\title{
The Islamic Republic of Iran: FACTS AND Fiction
}

\author{
Jahangir Amuzegar
}

Dr. Amuzegar served the pre-revolution government of Iran as minister of commerce, minister of finance and ambassador-at-large. He was on the Executive Board of the International Monetary Fund, representing Iran and several other member countries between 1974 and 1980. He has taught at UCLA, the University of Michigan, Michigan State University, the University of Maryland, American University and Johns Hopkins SAIS. He is the author of seven books and more than 100 articles on Iran, oil, OPEC and economic development.

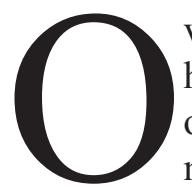
ver the last three decades, Iran has been a prominent feature of the world press and global media. Not a week has passed since November 4, 1979 — when 52 American diplomats were taken hostage in Tehran - without the clerical government being captured in the international spotlight. The near-daily news about the hostage situation, the Iran-Iraq War, and Washington's Iran-Contra fiasco were followed by reports of alleged terrorist bombings in Lebanon, Saudi Arabia, Argentina and Africa, along with dispatches about assassinations of political dissidents and critics at home and abroad. Later on, attention was focused on political mischief in Iraq and Afghanistan involving U.S. and NATO forces, as well as increasing political repression and human-rights violations at home. Then, reports about clandestine uranium enrichment and nuclear development programs, subse(C) 2012, The Author quent UN Security Council sanctions, and other multilateral or unilateral penalties became headline news. And, lately, extensive reports about an alleged terrorist plan to assassinate the Saudi ambassador in Washington, the storming of the British embassy in Tehran by a shadowy group presumably angered by the Cameron government's sanctions on Iran, the downed U.S. Sentinel stealth drone in northeastern Iran, and Tehran's threat to close the straits of Hormuz in case of total embargo on Iran's oil exports have supplied the ravenous international media with continuous, and at times sensational, material.

Despite this nearly ceaseless publicity, however, some fundamental characteristics of the Islamic regime have escaped proper scrutiny and are shrouded in myth. The regime's true political nature, the country's constitutional structure, the power and position of its top leaders, the political challenges it poses to the region and the world, 
Middle East Policy, Vol. XIX, No. 1, Spring 2012

the reasons for its long-term viability in the face of stiff global sanctions, and its ideological influence on the region's political movements remain largely misunderstood and misinterpreted. This brief review attempts to dispel seven of these myths.

\section{(1) The Islamic Republic is one of the Middle East's vibrant democracies, since it holds regular elections for its office holders.}

This is not only an exaggeration; it is essentially misleading. The Islamic government has, since its inception in 1979, held regular periodic elections for its major elective offices - the presidency, the Majlis (national assembly), the Assembly of Experts and municipal councils. Supreme Leader Ali Khamenei has called these elections "one of the Islamic regime's main pillars, a symbol of political maturity, and a national pride." But none of these elections can claim to have been a manifestation of real participatory democracy, for several reasons. To begin with, none has been deemed totally free and fair, and every one has been tarnished by reports of fraud and irregularities. Some, like President Ahmadinejad's reelection in 2009, have been widely contested and were followed by massive street demonstrations and popular protests.

Furthermore, none of these elections can pass the test of true popular representation: the people's free choice. By law, candidates for any elective office in Iran must be individually screened and approved before election campaigns by a special 12-member Council of Guardians, a cornerstone of the Islamic Republic. A quintessential qualification for candidacy, among others, is a "demonstrable loyalty" (eltezam-e amali) to the concept of rule by an Islamic jurist (velayat-e faqih). The
Council can, and frequently does, reject candidates' eligibility on this and other vague grounds. Thus, in a Soviet-like procedure, only loyal candidates (khodi) are eligible to run, and all others (geir khodi) are excluded. In some elections (March 2012, for example), members and affiliates of several political parties, along with 2,700 out of nearly 5,000 registered candidates were not allowed to participate. Majlis candidates (except the incumbents) must also possess a master's degree from a domestic or foreign university. Deputies have no immunity from prosecution and can be hauled before the courts. And, according to a law recently passed, duly elected deputies can be expelled from the assembly during their terms of office if found disloyal to the concept of velayat.

In addition, democracy is not just a political structure: it has its cultural, social and economic dimensions. A true democracy, in addition to having free and fair elections, requires (a) respect for certain universal values (such as basic civil rights); (b) certain institutions (a free press, active political parties, nongovernmental organizations, trade unions, professional associations and similar civil entities); and (c) the rule of law and an independent judiciary as the ultimate guarantors of democratic rule.

The Iranian record on the first prerequisite is clearly dismal. As shown by the ninth consecutive annual censure resolution by the UN General Assembly since 2003 and periodic reports by the United States and other Western countries, Human Rights Watch and Amnesty International, basic human rights are routinely and flagrantly violated by the Islamic Republic. Individual daily lives are strictly regimented; personal freedoms (choice of food, clothing, entertainment and recreation) 
are all controlled. Dissenting journalists, student activists and defendants' lawyers are arrested on trumped-up charges. False confessions are extracted under torture and presented to Stalinist-type courts to obtain long prison sentences. Members of nonShia faiths and other minorities are routinely mistreated. Iran's economicfreedom rank in the 2012 report by Freedom House is 171

A prominent theoretician of the regime claims that the Iranian system should be called the government of "Islamic Justice," a term he claims Ayatollah Khomeini preferred over "Islamic Republic," which he grudgingly accepted only as a matter of expediency. total ruin." Manned by a group of incompetent and often corrupt political hacks with little or no background in law, the regular and "revolutionary" Islamic courts are charged with the implementation of a seventh-century-type penal code. These courts regularly mete out barbaric penalties (stoning to death, blinding, amputations and public flogging) and the world's highest per out of 179 countries. In political freedom and respect for human rights, it scores seventh, the lowest position in a sevencategory scale.

The second prerequisite of a functioning democracy, the vitality of civil society, is also lacking in Iran. The press is censored. The Islamic Republic's rank in press freedom, according to the 2012 report by the Reporters Sans Frontières, is 175 out of 179 listed. The New Yorkbased Committee to Protect Journalists describes Iran as the jailers of the highest numbers of press reporters in the world, with 42 behind bars in December 2011. Radio and television are state monopolies. Connections through Internet, Facebook, Twitter and other social media are frequently jammed. Political parties are tightly regulated. Trade unions are banned. Lay professional associations are stigmatized. Nongovernmental organizations (NGOs) are selectively allowed to operate.

Third, a competent and independent judiciary, as the ultimate safeguard of democracy, is conspicuous by its absence and is described by its previous chief as "a capita number of executions. The latest annual report of the World Justice Project, measuring respect for the law and citizens rights, places Iran at the very bottom of the 100 countries observed.

(2) Iran's "Islamic democracy" could be a suitable model for newly triumphal Islamic parties in such countries as Tunisia, Morocco and Egypt.

This is both erroneous and wrongheaded. The Islamic Republic's apologists at home and abroad, feeling selfconscious about the incongruity between their "democratic" system and a typical Western variety, have propagated the fiction that their "Islamic model" is an ideal form of government because it is headed by an eminent theologian - a man of God selected by his peers, who themselves are elected by popular vote.

There are two flaws in this bizarre claim. First, whether or not God's government on earth is superior to man's rule, the term "Islamic democracy" is self-contradictory and oxymoronic. Democracy, as its Greek origin signifies, is rule by the 
Middle East Policy, Vol. XIX, No. 1, Spring 2012

people. Religion can never be a vehicle for democracy. There is no religion based on democratic rule. Islam, like all other religions, is based on faith; democracy is based on a social contract. Democracy is composed of citizens regardless of their faith; Islam is composed of believers regardless of their citizenship. Islamic sharia is the reflection God's rule on earth as prescribed by the Quran. The first and second clauses of Iran's 1979 constitution describe the regime as the manifestation of God's rule on earth. The state is headed by a vali-e faqih, who leads the country on behalf of the occult (hidden), Twelfth Imam. His orders (hokm-e hokumati), based on his understanding of Quranic principles, must be obeyed by every citizen, even if opposed by the majority. The people's wishes and votes would be respected only so long as they remain within the sharia's mandates and the vali's edicts. God's incontestable rules can never be remanded by the people's fickle votes, even by a 99 percent majority. A prominent theoretician of the regime claims that the Iranian system should be called the government of "Islamic Justice," a term he claims Ayatollah Khomeini preferred over "Islamic Republic," which he grudgingly accepted only as a matter of expediency.

Second, whether or not the ruler's access to power through popular vote is superior to other selective techniques, the matter does not apply in the case of Iran. True enough, the 86-member Assembly of Experts (all male clerics), which selects the vali (supreme leader, or rahbar) is elected periodically by direct popular vote. But this selection is currently a matter of debate. A recent interpretation by one of the rahbar's own favorite theologians claims that Iran's supreme leader is in fact "desig- nated" and "selected" by God himself and only "discovered" by the Islamic theologians of the Experts Assembly.

In any event, none of the assembly members is actually a free agent; by law they all must first be screened and approved by the 12-member Council of Guardians. The Council itself, however, consists of six theologians appointed by the supreme leader, and six lay jurists selected by the Majlis from a list of nominees submitted by the judiciary chief. The chief justice is himself appointed by the supreme leader and is naturally expected to select nominees loyal to the rahbar. The Majlis deputies, who are supposed to select the council's lay members from among the judiciary chief's nominees, are themselves all screened and approved by the Council of Guardians and loyal to the rahbar. Thus, in a near-magical manner, the supreme leader appoints himself to the post!

As a further manifestation of this incestuous political process, some members of the Council of Guardians also serve in the Assembly of Experts. Nearly all members of the assembly are Friday prayer imams appointed by the rahbar, or they are the latter's representatives in various public organizations. Another example of the assembly election farce is that, in some precincts, there is only one candidate, no contestant and an outcome that is known beforehand. There is no time limit for the rahbar's tenure. Members of the Assembly of Experts are supposed to supervise his performance and remove him from office in case of incapacity or poor performance. But they usually meet twice a year and routinely issue endorsing proclamations. It is highly doubtful whether the recently triumphant Muslim people of North Africa would crave such a template. 
(3) Supreme Leader Seyyed Ali Khamenei is one of the world's last remaining dictators and has unchecked religious and political power over all Iranian affairs.

A popular American magazine not long ago portrayed Iran's supreme leader as one of the world's 10 remaining dictators. Another business periodical has recently found him among the world's most powerful leaders. This is not only overweening hyperbole, it is essentially untrue. While some regime-financed clerics and sycophantic bureaucrats may call Ayatollah Khamenei the chosen emissary of the Prophet Mohammad on earth, he is neither a supreme religious authority nor a political dictator. In the unwritten Shiite hierarchy, he is a mid-level clergyman (hojat-ol Islam) whose title of "ayatollah" was not acquired through proper clerical procedures (writing a resale, or thesis). It was bestowed on him by lay politicians when he was elected supreme leader in 1989 after Ayatollah Khomeni's death. He may be regarded as a marja (source of emulation) by the poor on the state dole, and he may aspire to be the leader of the Muslim world, but he is generally dismissed by grand ayatollahs in Qom and Najaf as a lightweight. He occasionally issues inconsequential fatwas (religious edicts) against wearing ties, teaching music, consuming gold-plated ice-cream or misusing Facebook. But they are generally ridiculed and ignored. He also uses the bully pulpit to issue annual proclamations such as the speedy privatization of state industries, crusades against corruption, efforts towards food self-sufficiency and doubling the national output through an economic jihad. But these exhortations have so far remained ignored and unfulfilled.
Within the political hierarchy, he is the titular head of state and commanderin-chief of the armed forces. But Iran does not have one-man rule. And his powers are not unlimited; they are specifically defined by the Islamic Republic's constitution. He is equal to other citizens before the law and can be removed from office in cases of incapacitation or loss of essential qualifications. A clear testimony to his limited power is provided by a speech he delivered in mid-October 2011: "Leaders of Iran's executive branch, the Majlis, and the judiciary, in the fulfillment of their duties, may take certain decisions which the rahbar may not like. But the rahbar has neither the right nor the power to interfere with those decisions unless the matter involves derailing the Islamic revolution."

As a protector and promoter of the Islamic revolution, he uses all his wits and wisdom in a delicate balancing act by keeping various power centers in tow. Having appointed a veterinarian with no military background as the chairman of the joint chiefs of staff, he maintains a watchful eye on the armed forces. By frequently changing commanders of the regular armed services (without cutting their salaries or perks), he clearly tries to ward off possible challenges from the military. By allowing the Islamic Revolutionary Guard Corps (pasdaran) to obtain an increasing chunk of lucrative development projects in no-bid contracts, he is seeking their total loyalty. And, by recruiting thousands of teen-age villagers and unemployed vigilantes into an informal militia (the baseej), he manages to keep street demonstrators subdued.

The most formidable latent challenge to his authority, however, comes from the financially independent grand ayatollahs in Qom, who enjoy vast amounts of public 
respect and support. They are a potent force that he has been trying to win over, time and time again, by his frequent trips to the city.

As a person, Khamenei is a cautious and calculating man, a master of balancing acts who protects his power and prestige by avoiding involvement in controversial issues and factional politics by appointing special commissions to resolve disputes. In reality, he presides over several political satrapies

[Ahmadinejad's] verbal assaults on Washington and Tel Aviv are nothing more than a parroting of Ayatollah Khomeini's numerous 1980s sermons; they are not his own constructs. manned by various oligarchs. In this powersharing, semi-sanctioned anarchy, tolerated conflicts abound: statutes duly enacted by the Majlis are ignored by the executive branch; decrees passed by the Council of Ministers are found unlawful by the Majlis; the Supreme Audit Court finds gross violations of budgetary appropriations. Yet no one seems to mind. And the show goes on under the rahbar's watchful eyes.

Unlike Machiavelli's ideal prince, Khamenei is neither widely respected nor truly feared. He is routinely obeyed by all because he has convinced other oligarchs that, in any shake-up, they would all come out losers.

\section{(4) President Mahmood Ahmadinejad is} a religious fanatic who truly believes in the imminent return of the twelfth Shia imam (mahdi), while posing as the main obstacle to a Tehran-Washington détente.

Ahmadinejad has a reputation for delivering crowd-pleasing and combative speeches full of bravado, falsehood and occasional vulgarity. His personal and managerial qualifications for the office may be questioned. But he is neither delusional nor crazy - as many in the West believe. $\mathrm{He}$ is a shrewd, street-wise and seasoned politician whose words and gestures, even those deliberately false or misleading, are carefully chosen to achieve specific objectives. He is a self-adulating and authoritarian leader, a demagogue masquerading as a populist, but he is not naïve. He may be the devout Muslim he pretends to be, but he is far from a clergy worshipper. In fact, his "lib-

eral" position on certain hot-button issues - overlooking violations of the Islamic dress code, allowing women to attend sports events, kissing the hands of his old female school teacher, giving interviews to foreign female reporters without full head cover, expressing pride in Iran's pre-Islamic history, and rejecting gender segregation in the Iranian universities - attest to his departures from clerical orthodoxy.

For these reasons, it is widely suspected that his entire twelfth-imam scenario is nothing but a clever ruse. It is believed that his expectation of the imam's imminent return, hints about having direct access to him, and claims of benefiting from his daily guidance on government affairs are all masterfully designed to clip the clergy's wings, if not implicitly question the sanctity of the valayat-e-faqih itself. For, in a situation where the country's daily public policies are specifically directed and supervised by the occult imam himself, there would hardly be need for a proxy, be it a vali or a rahbar.

In the matter of hostility toward Washington, too, Ahmadinejad's role is largely 
misunderstood. His regular anti-capitalist diatribes and grandstanding against the United States may give the impression of a personal anti-Americanism. But this has been merely an act. His oft-quoted bellicose statements about "wiping Israel off the map" and his denial of the Holocaust may have also seemed an obstacle to reconciliation with the United States. This has hardly been the case, however. His verbal assaults on Washington and Tel Aviv are nothing more than a parroting of Ayatollah Khomeini's numerous 1980s sermons; they are not his own constructs. In fact, among Iran's current political leaders, he is probably the most eager closet advocate of resuming diplomatic relations with the Great Satan.

Ahmadinejad's actions in this regard betray his narrative. He is the only president of the Islamic Republic who has congratulated an American president on an election victory. He has written letters to both Presidents George W. Bush and Barack Obama proposing a dialogue. In his annual trips to New York for the UN General Assembly, he has repeatedly asked to meet with U.S. leaders, to no avail. During his last trip, in September 2011, he welcomed the establishment of a hotline between Iranian and American naval units in the Persian Gulf in order to avoid unintended mishaps. And his many suggestions for solving Iran's uraniumenrichment and nuclear-development programs have been the most conciliatory of any Iranian leader. His revered guru, best friend and close relative, Esfandiar Moshai, is rumored to have been making behind-the-scenes contacts everywhere to advance his reconciliation objective. Interestingly enough, the alleged plot to assassinate the Saudi envoy in Washington is rumored to have been hatched by
Ahmadinejad's political enemies in order to nullify his pro-American démarche.

The deadlock in Tehran-Washington relations goes far beyond personal grudges or preferences. The enmity towards the United States has been the cornerstone of the Islamic regime's identity, legitimacy and staying power from day one. It has been based on Ayatollah Khomeini's xenophobic posture and opposition to Mohammad Reza Shah, whom he accused of promoting American and Israeli interests. Ayatollah Khamenei's well-guarded leftist tendency, his unwavering championship of the Palestinian cause (sporting a kaffieh in public appearances) and hostility toward the Jewish state (objection to the two-state solution) follow the same line. The rahbar's need for a bogeyman to be blamed for Iran's various setbacks as well as his own numerous failings may also have found hostility to Washington a perfect ploy.

In addition to this deep-rooted individual hostility, a major force behind continued enmity toward Washington emanates from the ultra-conservative clerical establishment, which sees the resumption of relations as the end of its hegemonic clout. Normal relations with Washington are seen by the obscurantist mullahs as the prelude to the so-called "Western cultural onslaught" - increasing political and social liberalization, rejection of outmoded Islamic moral codes, a welcome adoption of Western democratic institutions and replacement of voodoo by modern science.

Normalization of relations with the United States is resisted by yet another powerful interest group in both the bazaar and the modern economy. Formed during the last 33 years of American absence, the group includes merchants, industrialists, service contractors and others who shifted their trade and business from the United 
States to China, Russia, East Asia, Latin America and Africa. They are likely to lose to new American rivals. Prominent among potential losers would be the Islamic Revolutionary Guard Corps, which currently enjoys a virtual monopoly in bidding for lucrative projects, and other Guard units widely suspected of being engaged in the increased smuggling of American products.

(5) Global economic sanctions have been to no avail since they have failed to change the regime's behavior or stop its nuclear program.

There is no dispute that, during the long period under sanctions, Iran has not only refused

to stop its

uranium

enrichment

program as demanded, but defiantly proceeded to develop more advanced After having categorically denied year after year that sanctions were having any effect on the Iranian economy, President Ahmadinejad has recently admitted that sanctions had virtually paralyzed the country's banking system, and called them economic warfare. international measures. Annual economic growth has been slowed and is currently hovering around 2.5-3.0 percent. Official inflation is over 20 percent, and the unemployment rate is in the mid-teens. Private estimates are much higher in both cases. Capital, labor and total-factor productivity are dismally small, in some cases negative. The climate for investment and business is poor, and there is rampant corruption at all levels of the government and in state enterprises, largely intensified by sanctions.

Thus, there is no doubt that the choreographed, multifaceted sanctions - by the United Nations, the U.S. Congress, the European Union and other countries - including freezing the assets and banning the travel of hundreds of Iranian individuals and businesses linked to Iran's nuclear procentrifuge capabilities. Furthermore, Tehran has accelerated enrichment of its uranium stockpile to 20 percent and has continued research on nuclear-warhead design. Yet all available evidence shows that increasing economic sanctions, cyber war, a terror campaign and a sabotage program (e.g., the suspicious killing of Iranian scientists, explosions in atomic and ballistic rocket centers, fires in oil and gas pipelines) have not only slowed down Iran's nuclear program, but extracted a heavy toll from the Iranian economy.

Long suffering from certain basic structural problems (gross mismanagement and ineffective leadership), Iran's economy has been further damaged by punitive gram - have had devastating effects. By all evidence, the Islamic Republic today is economically weaker and more chaotic, diplomatically more isolated and altogether more vulnerable than before. After having categorically denied year after year that sanctions were having any effect on the Iranian economy, President Ahmadinejad has recently admitted that sanctions had virtually paralyzed the country's banking system, and called them economic warfare. Scattered private reports point to such variegated sanctions-induced setbacks as a notable decline in daily oil production due to a lack of gas injection; a 20-30 percent increase in import costs due to higher banking, insurance and shipping charges; 
a shift from higher-quality Western goods to cheaper Chinese substitutes; difficulties in opening letters of credit and transfers of funds in almost all major international banks; virtual stoppage of Western direct investments and technology transfers; the near-impossibility of issuing foreignexchange bonds in financial markets; and highly disturbing gyrations in the domestic gold and foreign-exchange markets.

The absence of change in the regime's behavior should be thus attributed to three countervailing factors. First, Iran's pursuit of advanced nuclear technologies, as well as its development of various nuclear capabilities, has now become a matter of national sovereignty, scientific achievement and patriotic honor the denial of which is universally considered close to treason even by the opposition. Second, a number of Islamic, non-aligned, left-leaning and anti-American countries, along with such veto-empowered governments as Russia and China, have refused to abide by tougher Washington and European sanctions and thus eased the burden. Cooperating banks and amenable oil refineries in friendly countries also helped fill some of the void. Third, large receipts from oil, gas and other exports during the last six years have enabled the regime to finance its annual budget, triple non-oil exports, double imports, and carry out a costly subsidy-reform program, thus lightening the sanctions' effects.

"Crippling" sanctions involving Iran's central bank and oil exports have recently been imposed on Iran by the United States and the European Union, avowedly in the hope of building public discontent and compelling the regime to change its nuclear policy. But, as long as the same political and economic realities prevail, little or no palpable change in the govern- ment's behavior should be expected. With an estimated $\$ 135$ billion from oil and non-oil exports in 2011-12, a chest reserve of $\$ 120$ billion in cash and 907 tons of gold (as reported by the Tehran Chamber of Commerce), Iran has more than enough resources to meet its payment obligations for more than a year. The government has a relatively small and serviceable foreign debt. And Iran can expect a continued positive trade balance as long as crudeoil prices remain above $\$ 80$ per barrel. Smuggling in and out of the country may also continue to play a significant role in easing the burden. Nevertheless, dark and stormy days for the economy are ahead. Some moderately positive reports about the Iranian economy from the International Monetary Fund and the World Bank in recent months, while clearly attesting to the economy's resilience, also confirm an eighteenth-century sage's dictum that "nations have untold capacity for ruin."

\section{(6) The only way to stop Iran from acquiring the nuclear bomb is to bomb it.}

This is a deceptive, futile and dangerous idea backed by some powerful political groups of ultraconservatives in the United States and Israel. The hawks' arguments for a preventive strike are fairly simple, if not very convincing. First, the Islamic Republic is determined to acquire nuclear weapons because (a) all its major neighbors (Russia, Israel, Pakistan and, by proxy, the United States) are already nuclear powers; (b) no country possessing an atomic bomb has ever been attacked; (c) the Tehran government cannot financially afford to match its adversaries in conventional weapons; (d) Tehran has publicly announced its uranium-enrichment capabilities to be up to 20 percent, thus becoming a "virtual" nuclear state; and 
(e) the November 2011 report by the International Atomic Energy Agency (IAEA) has showed that Tehran is involved in "efforts to master the technology needed for atomic weapons" and is not forthcoming in its various nuclear-development activities.

A nuclear-armed Iran, in the neocon view, should thus not be allowed to proceed: because (1) it would lead to an arms race and nuclear proliferation in the region; (2) it would immensely increase Tehran's prestige in the Middle East, and enable it to use the nuclear umbrella to establish its regional hegemony, forcing smaller countries into its orbit; and (3) it would pose an existential threat to the state of Israel. At the same time, preemptivestrike proponents argue that the U.S. Cold War policy of containment/deterrence visà-vis the Soviet Union and China would not stop the Islamic Republic from using its nuclear weapons. Their reasoning: the Iranian regime is shaped by a messianic cult and run by fanatical mullahs who place the highest value on martyrdom and life in the hereafter, thus making annihilation a welcome event!

The flaws in these arguments are many. First, they ignore Tehran's repeated and emphatic denials and fatwas issued by Ayatollah Khomeini and other grand ayatollahs against nuclear use. Second, even if Iran were actually engaged in developing a nuclear device, bombing Iran's nuclear facilities would be neither practical nor effective, as several highranking American and Israeli authorities have repeatedly pointed out. Iran is not Iraq or Syria with a fixed, open and known nuclear facility and no possibility of retaliation. Bombing multiple Iranian sites near population centers would require many air sorties, causing heavy human casualties and dangerous nuclear fallout. Invading planes could be shot down and their crews taken prisoner. Iran could close the Strait of Hormuz, sending oil prices sky high and damaging the global economy. American and allied ships and installations in the Persian Gulf could be attacked. In short, there could be no "clean and calibrated" air strikes, but a violent and messy affair with untold consequences. New insurgencies in Iraq and Afghanistan could be instigated. An American or Israeli attack on Iranian sites is also bound to trigger a catastrophic regional war involving the Lebanese Hezbollah, Palestinian Hamas, Syria, Saudi Arabia and other Gulf Cooperation Council members.

On top of all these, even the successful bombing of Iran's nuclear facilities with bunker-busting shells might temporarily cripple the nuclear program, but it will not stop it. In fact, it may unify the opposition behind the government and encourage the Tehran regime to redouble its nuclear efforts. Installations may be destroyed, but knowledge cannot be wiped out of scientists' minds.

Third, and most significant, the Iranian clergy's alleged character traits are grossly misunderstood. The concept of the "hereafter-fixated mullahs" is a complete fiction. A cursory look at the ruling clergy's mode of living in Iran - multiple wives, spacious living quarters, luxury cars, foreign bank accounts, sumptuous wedding and anniversary parties for their offspring attests to their love for life and fear of death. Shiite clerics in Iran may reject certain aspects of Western culture, but they are hardly suicidal.

In many experts' views, a deterrence policy is probably the most cost-effective way to deal with the situation. 
(7) Iran's massive pro-democracy demonstrations of 2009 - the Green Movement - have been the main inspiration for the uprisings in the Arab world, the so-called Arab Spring.

This connection seems highly farfetched, for several reasons. First, the lapse of time between Tehran's June 2009 street demonstrations and the first spark in the Tunisian uprising in December 2010 makes the events too distant from one another to be correlated. Second, the nature of the riots, the protesters' demands and the dynamics of the discourse have been vastly different in the two cases. In Tunisia, as in Egypt, Libya, Syria, Bahrain and Yemen, grievances were about dictatorial regimes that had resulted in mass unemployment, high inflation, rampant corruption and rising poverty. In Iran, the complaints focused solely on the rigged presidential elections and "lost votes." Similarly, the demonstrators' demand in the Arab world was straightforward: the ouster of the long-ruling dictators. In Iran, there was no demand for regime change or the supreme leader's dismissal. Third, the Arab uprisings were generally leaderless and sprang almost spontaneously from the frustrated, aggrieved and unemployed youth seeking a better material life. In Iran, the "Green Movement" was backed by two aging former officials and solid members of the Islamic Regime's nomenklatura who were deeply and personally involved in some of the regime's questionable deeds. These "opposition" leaders did not push for the theocracy's downfall. They wanted, in fact, to go back to Ayatollah Khomeini's "golden era," his "true teachings" and a strict observance of Iran's Islamic constitution.

The much later demonstrations in Iran during 2010 - which involved faint chants against the rahbar and scattered stifled demands for Khamenei's ouster have themselves, ironically, been influenced by the Arab Spring, rather than the reverse. The new anti-rahbar cries started after Ben Ali's ouster in Tunisia and Mubarak's in Egypt.

\section{Avoidable Pitfalls}

The distorted picture that these myths present goes beyond mere abstractions. The myth of a popularly elected government in Iran and the fiction of an "Islamic democracy" propagated by the regime's mouthpieces around the world have enabled the Islamic Republic, one of the world's most notorious misogynist regimes, to gain a seat at the UN Commission on the Status of Women, the principal world body dedicated exclusively to gender equality.

The exaggerated notion about Ayatollah Khamenei's absolute power and unique prestige has deflected attention from the fact that, since the end of the Iran-Iraq War, Iran has been steadily moving from a theocratic oligarchy towards a quasi military dictatorship in which the top brass, masquerading as devout Muslims, enjoy not only increasing political clout but also 
Middle East Policy, Vol. XIX, No. 1, Spring 2012

growing financial power - with dire consequences for the country and the region.

The myth about President Ahmadinejad being responsible for the Tehran-Washington rupture has camouflaged the real stumbling blocks. The reason Ayatollah Khamenei and other top political leaders have been reluctant to engage in a serious dialogue with Washington is not essentially a clash of personalities or hostility toward a grand bargain, but simply a matter of profound mistrust. In March 2010 Ayatollah Khamenei rejected President Obama's "extended hand" (of friendship) by calling it a "steel hand inside a velvet glove." Rightly or not, Iran's political leaders are convinced that Washington's ultimate objective regarding Iran is "regime change," and that all the talk about nuclear weapons or human-rights abuses is sheer political subterfuge. A recent newspaper report, attributed to an unnamed Washington official, indicates that the sanctions are designed to create enough popular discontent to force a change. Thus, unless and until the Iranian leaders are disabused of this notion, there will be no gesture of reconciliation from the Iranian side. At the same time, given the current make-up of the U.S. Congress and the domination of U.S. politics by special-interest pressure groups, Tehran's overt and unrelenting hostility towards the state of Israel, as well as its undisguised opposition to the two-state solution, will prevent Washington from considering any genuine détente with Tehran.

The illusion about the futility of sanctions has played into the hands of those who advocate "neutralizing" the Iranian nuclear threat rather than containing it. Ignoring the devastating effects of sanctions and coercive measures on ordinary Iranian citizens - consequences explicitly claimed to be unintended by the Obama administration - American and Israeli hardliners are emboldened to propose yet stiffer and more coercive measures.

The fiction concerning Iran's nuclear ambitions has complicated Iran's normal relations with its neighbors and the international community at large. It has led the hawks to get ahead of the facts and overplay the significance of the Islamic Republic's drive for nuclear technology by falsely claiming that the latest IAEA report finds Tehran on the threshold of having a nuclear bomb. And the preposterous notion about the mullahs' craving for martyrdom and defiance of mutual annihilation has likewise prompted the warmongers to push for early preventive strikes.

Finally, the false notion about the Arab Spring's emanating from Iran's Green Movement has enabled the Islamic Republic's propaganda machine to portray the North African uprisings as a "great Islamic awakening," a "struggle against the West," and a "revival of Islamic rule." In truth, none of these movements has showed any similarity to Iran's 1979 revolution. There have been no "death to America" or "death to Israel" slogans, no burning of the American flag, and no demands for an Islamic government. In their general yearning for freedom, democracy and respect for human rights, there has been a clear rejection of an Iranian-type Islamic rule. Interestingly enough, in the UN General Assembly votes on Iran's 2011 human-rights violations, Tunisia and Libya voted against the Islamic Republic, and Egypt abstained.

A clearer understanding of these myths may not end the West's Iranian conundrum, but it might lead to less swashbuckling and more effective ways of dealing with it. 